\title{
CROWDSOURCING AS A METHOD OF OBTAINING INFORMATION
}

\section{Natalia PRZYBYLSKA}

The Faculty of Economics and Management, Nicolaus Copernicus University in Toruń, Poland e-mail: nataliap@doktorant.umk.pl

\begin{abstract}
The aim of this article is to analyse and describe a new trend in obtaining information and solving problems, which is crowdsourcing. Contemporary enterprises face enormous challenges, which are connected with omnipresent changes occurring in the functioning of societies and economies all over the world. Crowdsourcing is a very complex and constantly evolving phenomenon. It is an open subject of multiple discussions in which, due to its multiple factors and variable applications, it is being differently defined. Growing usage of this phenomenon prompts scientists for undertaking research and analysis of this issue as it is strictly connected with dynamically changing attitudes of, not only, entrepreneurs, but also their surroundings. The prime driving force behind undertaking this subject is a fast development of technology, Web 2.0, or globalisation. The mechanism of crowdsourcing's functioning has been known for ages; however, it was named as a tool for modern enterprises 10 years ago. During that short period of time crowdsourcing has gained the acceptance of a number of people all over the world. The challenge for the present research is, as well, to indicate advantages and underline the essence of proper managing of crowdsourcing in enterprises, what involves a number of aspects. The described solution is still gaining more and more proponents; however, planned inappropriately, may cause completely reversible effect than the desired one. In this article, descriptions of worldwide ventures, which apply crowdsourcing, in Poland as well, and the results of the newest research on the phenomenon were included.
\end{abstract}

Key words: crowdsourcing, innovations, Web 2.0, prosumerism, outsourcing.

\section{1}

\section{Introduction}

Modern enterprises function in constantly changing conditions. The acceleration in the production of goods based on knowledge, meeting expectations of more and more demanding clients determines the functioning of economic entities all over the world. According to the OECD's statistics, almost 1 billion USD is being spent on new knowledge every year. Nowadays, the manufactured products and offered services are more often distributed globally. As a result of the growing globalisation, the fragmentation of markets, which are strongly differentiated and dispersed, occurs. It causes far-reaching effects. One of them is the necessity to monitor not only the local market, but also the global one [1, pp. 37-38]. The Internet is not only a rich source of information, but also a way to communicate or distribute goods. The growing development of cyberspace conditions the functioning of enterprises and societies in almost every sphere of life. The activity of economic entities depends whether they will be able to find themselves in a new reality, what requires the application of modern technological solutions. Because of the increasing virtualisation of enterprises, the speed of operation and reliability are seem to be more meaningful than ever before [2, pp. 15-16].
Facing up the reality, requires possessing by enterprises such characteristics as innovativeness or elasticity. They allow to preserve the dynamic balance with the surrounding. Present organisations are aware of the intense competition and of how many new channels of distribution and promotion it operates with. Therefore, those entrepreneurs who want to achieve a success undertake innovative actions, which can provide them a competitive position on the market [3, p. 261]. Changes on our world lead us to a new era, which is characterised by intense participation of people in the global production. Forms of mass cooperation and co-creation change the existing business models. A widespread access to the Internet and modern technologies enable us to jointly undertake innovative actions [4, p. 28]. Nowadays, the consumers are not only the final recipients of goods and services, but they also take an active part in creating new products. They take over the role of the previous producers. The new type of a client, who actively participates in the production process, is named as the prosumer. The development of Web 2.0 is a perfect environment for the development of social platforms and, what follows, prosumerism. The Internet escalates the development of proactive attitudes in two ways. At first, it enables to contact everywhere and anytime; secondly, it is a perfect tool to share information and 
Table 1. The comparison of crowdsourcing with outsourcing (source: own elaboration based on: [7, pp. 75-77; 8, pp. 1-34; 9, pp. 93-113]).

\begin{tabular}{|c|c|}
\hline Crowdsourcing & Outsourcing \\
\hline $\begin{array}{l}\text { Global footprint - there is no fixed location, e.g. office, coworkers } \\
\text { can be everywhere by participating only virtually. }\end{array}$ & $\begin{array}{l}\text { Local footprint - operating only in some fixed } \\
\text { locations, which fulfil certain requirements. }\end{array}$ \\
\hline $\begin{array}{c}24 / 7 \text { - virtual crowds can work not only everywhere, but also } \\
\text { anytime. There are no fixed working hours. The only limitation is a } \\
\text { deadline. }\end{array}$ & A fixed deadline and specified working hours. \\
\hline $\begin{array}{l}\text { Payment depends on the results of work - salary is given to a person } \\
\text { whose work will be the best but cooperated with others. The final } \\
\text { result is evaluated. There are no employed persons. }\end{array}$ & $\begin{array}{l}\text { Payment for a certain job made for external } \\
\text { company. }\end{array}$ \\
\hline $\begin{array}{l}\text { Cost-cutting - the cost is an award for the winner, which is estimat- } \\
\text { ed by a company; there are no legal recruitments. }\end{array}$ & $\begin{array}{l}\text { The costs of a given job are for external company. } \\
\text { Fixed costs are changed into variable costs. }\end{array}$ \\
\hline $\begin{array}{l}\text { Limited control - an entrepreneurship has got a limited control as } \\
\text { the crowd working for it is anonymous and virtual. Only the access } \\
\text { to the project may be somehow controlled. The final result is often } \\
\text { unknown, there is an unlimited number of solutions, which are be- } \\
\text { ing chosen according to specific criterion. }\end{array}$ & $\begin{array}{l}\text { An entrepreneurship does not have a complete } \\
\text { control but it knows what is the expected result. }\end{array}$ \\
\hline $\begin{array}{l}\text { Crowdsourcing is a huge source of innovation. An unlimited number } \\
\text { of people work on a certain problem or idea, which exceeds often all } \\
\text { of the entrepreneur's expectations. The result is often very surpris- } \\
\text { ing or innovative. }\end{array}$ & $\begin{array}{l}\text { Outsourcing does not favour innovations; there is } \\
\text { only a certain work to be done, which is strictly } \\
\text { described and the result shall not be surprising but } \\
\text { it should meet some previous recruitments. }\end{array}$ \\
\hline $\begin{array}{l}\text { Very differentiated group of people works on the project. A crowd } \\
\text { consists of experienced professionals, as well as, amateurs having } \\
\text { a fresh creative look. As it results from many research conducted } \\
\text { on a group work, variety gives valuable effects so that a number of } \\
\text { aspects for solving the problems occurs. }\end{array}$ & $\begin{array}{l}\text { A group of professionals and specialists in their } \\
\text { fields works on the project. }\end{array}$ \\
\hline $\begin{array}{l}\text { Certain jobs are usually devoted to aspects connected with solving a } \\
\text { given problem or searching for ideas }(B+R) \text {. }\end{array}$ & $\begin{array}{l}\text { There may be ordered works from the field of IT, } \\
\text { ancillary operations, as well as, logistics. }\end{array}$ \\
\hline
\end{tabular}

multimedia resources $[5$, p. 26, 27]. Prosumption is one of the driving forces in the changing world of business, which is not based on the complete number of products, but on creating the ecosystem of innovations. Users shall not be perceived only as clients, but rather by partners. The present consumer is much more educated and welloriented, therefore, he or she wants to have more intense influence on future which he or she co-creates. Entrepreneurs, in order to compete and develop successfully, must accommodate the prosumers, take the initiative, and benefit from surrounding possibilities [4, pp. 212-217; 6, pp. 170-174].

\section{The essence of crowdsourcing}

The 21 st century cooperation is undoubtedly crowdsourcing - the model of solving problems and developing products and services with the use of virtual crowds. Organisations establish the cooperation with an unidentified crowd by uploading in the web 'an open call' in order to work on a specific project. Creators of the best solutions are usually somehow awarded. A company becomes the owner of an idea and uses it in practice, simultaneously benefiting from [7, pp. 75-76]. Crowdsourcing consists of three components, such as virtual crowd, outsourcing of some previous inside organisational processes, and applying Web 2.0. Crowdsourcing is the model of out- 
sourcing which is located in the middle of outsourcing and advanced Internet technologies (Table 1) [8, pp. 1-3].

The term 'crowdsourcing' was first used by J. Howe and M. Robinson in June 2006 in 'Wired' magazine. They defined this phenomenon as a new model of business based on web, using creative solutions invented by virtual societies which answer open questions. In other words, an entrepreneurship announces in web that it searches for a solution to a given problem and an unlimited number of individuals offer solutions for it. The best idea is awarded and used [10, pp. 1-4]. Crowdsourcing enables entrepreneurships not only to find solutions for their problems, but also to acquire new ideas outside the company and, in the same time, limit the involvement of resources and save the time spent on the development of the idea from its bases.

Crowd and the Internet technologies create Web $2.0-$ websites, which were constructed after the year 2001 and in which the main role is played by contents made by the users of a given website. Web 2.0 is not new World Wide Web, but a new way of using its resources. Web 2.0 websites have changed the way of interaction between their owners and users, giving, in the same time, more space in creating contents to the hands of the users. The essence of Web 2.0 has an important influence on the development of social media, the Internet's applications, or blogosphere. Web 2.0 enables the users to interact and integrate more freely. The Internet users visit personalised websites and become, somehow, their co-creators by providing contents (among others, pictures, videos, links to other Internet sites, etc.) and building the users' societies, which cooperate with each other [11, pp. 1-4].

Nowadays, enterprises are using more often Web 2.0 in order to improve their internal processes and establish cooperation with the environment - clients, suppliers or partners. Every Web 2.0 website enables to interact with others in a new way, namely it goes beyond standards, offering the clients a new quality. It is possible to publish and share information, creating, at the same time, a website from its contents to the projects of almost everything connected with life (e.g. the virtual world of Second Life) or products of the favourite brand, or any other organisation which is present in the Web. The user, with the help of the above services, may be included to the process of creating the product in its initial phase (creating the idea of the product), as well as in its final phase (marketing or distributional). Research carried out in The McKinsey Global Institute proves that the enterprises applying Web 2.0 on a large scale, achieve better economic results and higher position in the market. The number of enter- prises using virtual social websites has been still rising. Therefore, entrepreneurs gain a series of advantages, such as growth of the accessibility to knowledge or external/ internal professionals, as well as, minimise the way to introduce novelties to the market and reduce costs. Adopting the technology of virtual societies facilitates, most of all, the flow of information inside the company, as well as in its surroundings. Furthermore, organisations using Web 2.0 adopt the attitude of learning organisations, what is an unavoidable factor for a proper functioning in hipercompetitious reality [12, pp. 117-120].

The meaning of crowdsourcing is strictly connected with a fundamental orientation on innovations. Presently, entrepreneurs build up a competitive vantage, creating innovativeness not only based on their own sources (in contrast to the past - based only on own research and development resources). Today, an effective method to achieve a success is to seize the outside opportunities through involving external entities in processes of creating and implementing innovations. Entrepreneurs are aware of the fact that they are unable to employ only the best workers and there is often a need to engage employees from outside of the company. Nowadays, it is possible to establish a cooperation with excellent external professionals. The role of such cooperation is emphasised due to a very simple reason, namely, there is no organisation which possesses all sources to achieve a stable market vantage [13, p. 156].

Crowdsourcing is an answer to the occurring doubts and needs of entrepreneurs, as well as, users. It provides enterprises an access to knowledge, information, readymade solutions and establishing relationship with the environment; whereas, clients are assured with the possibility to have a real influence on creating products and services. Knowledge and abilities of people from all over the world may serve to the economic practice and the overall development.

The power in crowdsourcing is reflected in three main perspectives. First of all, it is cost saving. A task, which is expensive to be done inside of the company and is connected with employing extra people, or other expenses, is given for an external consideration. Publishing a problem outside not only saves the time spent for the task realisation, but also costs of employment and conduction of a research. Secondly, the effectiveness of work is increased through employing a large number of people. People engaged in the project are frequently clients who are well acquainted with a product, service or brand. They see them from a different perspective - other than the one of a company's workers. Applying modern Internet plat- 


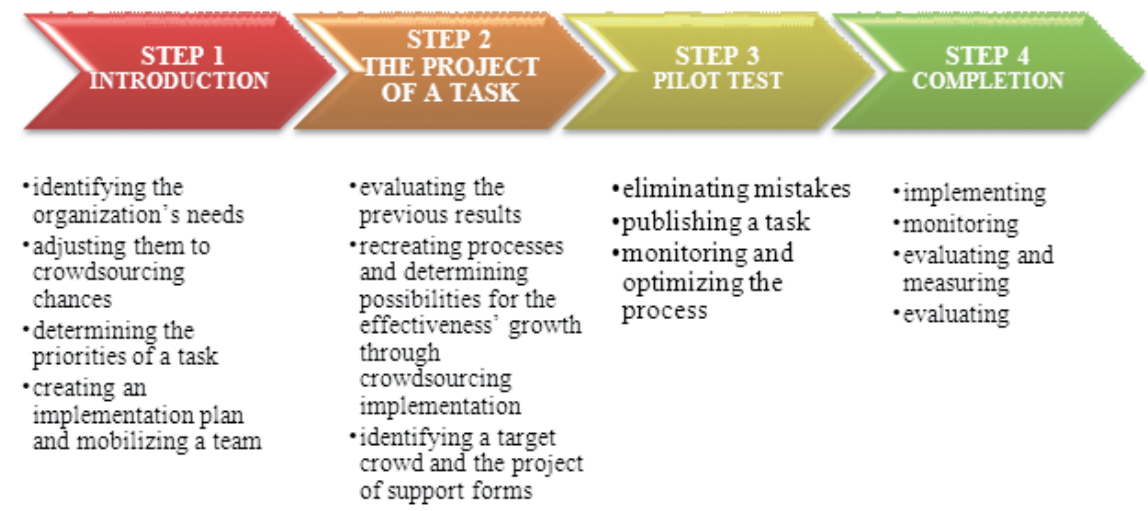

Figure 1. The process of crowdsourcing implementation [16, p. 12]

forms shortens also time of a tasks' completion. Opening a company for a cooperation with the environment has, as well, many advantages connected at least with its image. An enterprise gains an opinion of an innovative company, bearing in mind the needs of a client, and engaged in a dialogue with the environment. Worth mentioning is the third perspective connected with the global labour market, which establishes a cooperation with the best professionals from all over the world without the necessity to employ them permanently [14, pp. 1-2].

Crowdsourcing, as every other model of business, must be properly planned and managed. The below scheme presents the most important steps, which are to be undertaken in order to implement the process (Figure 1). Organisations willing to use the crowdsourcing must distinguish tasks which would provide them the largest advantages on an attractive level of effort. Therefore, the first step is to search for tasks which fulfil this criterion. Then, tasks must be precisely described and specified in order to find those which could take the advantage of an elastic supply and they shall be published outside of the company's frames. Managers shall consult on every decision with all the interested parties which will have an influence on the effectiveness of crowdsourcing. In this manner, a construction of the new process is being created. Next step is a project of the task. Here, it is important to remember that the task will be available for everyone, participants may be from different trades or countries; therefore, it is necessary to prepare profiles of our target groups, define informative needs, accomplish exhaustive descriptions, share as many as possible important data, as well as, define the criteria for the tests' evaluation. A pilot test is the next step to take. It shall be available only for a limited number of users and shall verify the accuracy of the prepared material or formulations. A test of the Internet platform and the prepared support tools is also important. The last but not least steps are to provide a proper management of the overall process, designate people responsible for the communication with a crowd, ensure the supervision of the sent solutions or current clarification of disputes through implementation of Frequently Asked Questions (FAQ) [15, p. 13].

In 2012 a report on using crowdsourcing, 'Crowdsourcing Industry Report', was written and published. Results of the Massolution company reveal that its main forerunners are large organisations those incomes are over 1 billion USD. Nine out of ten global brands from the ranking of Interbrand - 'Best Global Brands 2012' (one of the most generally admitted ranking of the worldwide brands) implement crowdsourcing. Global companies were using this model as, for example, a tool for acquiring a feedback from the users, what improved the existing products (Google), helped to create new products and services (IBN), as well as, created marketing campaigns (Coca Cola). Furthermore, sector, which specialises in crowdsourcing solutions for enterprises, maintains an intense upturn [16].

The model of crowdsourcing is constantly evolving. It is a novelty which intrigues and prompts to conduct a research. Motivations of people - 'crowd', which answers to the open call, are unknown. The undertaken research indicates that these motivations are influenced by a number of factors, starting from financial gains, award, the level of a task's complexity, the connection with interests, the probability of winning, but also the possibility to self-develop, the improvement of one's abilities, appreciation and satisfaction resulting from completing the task [14, p. 3].

The present model, as any other, is burdened with particular limitations and threats. With the growing popularity, the controversy rises as well. Critics state that it consti- 
tutes a danger for specialists employed in a company and it can be demotivating, finally influencing also on aspects connected with salary or hiring certain employers. There are also limits when it comes to tasks being shared with a crowd; a risk connected with publishing certain information or managing a large number of solutions, their selection and choosing the best one. A threat occurs also in terms of lack of interest between virtual societies, insufficient resources for adequate planning of the project (including a proper platform, the manner of communication with a crowd, award for the winner or the lack of the final solution or a practical inability for its implementation). A problem appears also in connection with the lack of employee-employer relationship, insufficient control and the influence on the society, which results from the absence of direct relations or written agreements [15, pp. 3-4].

Nevertheless, crowdsourcing is the trend which means constantly rising. A growing number of entrepreneurships implementing it in practice prompt to become more acquainted with it. For this reason the next section is devoted to its practical usage.

\section{The practical use of crowdsourcing by pre- sent companies}

Crowdsourcing is an innovative way for searching solutions for modern enterprises. The largest worldwide companies use it willingly in practice. More often, coauthors of crucial ideas are clients, suppliers, partners, as well as, people from down under who are not at all connected with an organisation. The present trend was used by the founders of the innovation exchange InnoCentive who have built a platform which integrates entrepreneurs searching for innovatory solutions with the initiators. It happens that the originators of the best ideas may win even 1 million dollars. One of the InnoCentive's mottos is - A breakthrough idea can come from every place all over the globe. A web portal unites entrepreneurs, nongovernmental organisations or national institutions. Entities, which search for innovation in their fields, upload on the web their offer, in which, except of a detailed description of a problem, information on a financial award for the founder of the most interesting solution is included. So far, over 40 million dollars have already been given to the hands of the originators. An award for the most complex problems reaches even from five thousand to one million dollars. The popularity of the web, started in 2001, is proved by a constantly rising number of users, which exceeded 300 thousand. The portal gathers presently users from almost 200 countries, who work every day to fulfil the largest needs of nowadays economy. Over 1650 offers have been already published in the portal, which gained altogether 40 thousand answers. It is worth mentioning about the high percentage of solved problems - even $85 \%$ of them find a satisfactory answer. The platform InnoCentive breaks large grounds before the worldwide economy - few hundreds of people would work on innovations or even few thousands of scientists at the same time. Professionals, registered in the portal, can not only help to overtake the competitors, but also find the best solutions for certain problems of the entrepreneurs [17].

The general director of GoldCorp Inc. was also guided by the idea of crowdsourcing. Rob McEwen, the CEO of that time of an enterprise dealing with extracting gold, was facing the threat of bankruptcy. The company was struggling with a number of problems, starting from its growing debts, the exhaustion of exploitable for 50 years resources of gold, ending with strikes. The manager, in spite of criticism and disbelief of coworkers, undertook almost a suicide attempt to rescue the company. At the meeting with geologists, he announced that he is up to find gold in the deepest and the most unavailable parts of the mine and that he will devote for this aim 10 million USD. Gathered at the meeting geologists had very sceptical attitudes toward the decision of their supervisor. Nevertheless, they decided to undertake the task and, surprisingly, they found that resources in this area are 30 times larger than those exploited previously. The discovery turned out to be a phenomenon; however, in spite of good intentions of geologists, they were not able to estimate the precise abundance of reserves and their location. McEwen, inspired by the example of Linux, decided to follow the steps of Linus Torvalds. He wanted to take the advantage of people outside of the company. He gathered all the accessible information about the reserves, saved them in files on computer, and published. Geologists employed in the entrepreneurship were not pleased about this idea and expressed their sceptical attitudes. Mining is an industry, in which information is extremely precious and usually carefully protected. The director admitted that his decision was very controversial and dangerous. In the year of 2000 the project 'Goldcorp Challenge' was announced. Its total award was 575 thousand USD for people who will describe the best estimations and methods of exploitation. Information spread immediately and in few weeks solutions from 50 countries were sent. Solutions were created not only by geologists, but also by mathematicians, physicians or graphic designers. The open call provided in- 
formation which was extremely surprising and revealed previously unknown possibilities. Participants specified a number of places which were not taken into consideration ever before. What is more, in more than $80 \%$ of new areas, they encountered rich reserves of gold. McEwen estimated that he had saved from 2 to 3 years of hard and expensive exploration works. The project influenced on the phenomena that the entrepreneurship worth 100 million USD struggling a number of problems, is now in value of about 9 billion USD and became the second, in view of its capitalisations, biggest corporation mining gold in the world. Furthermore, previously undeveloped mining region of Northern Ontario became one of the most innovative and profitable area in this branch. The strategy applied by Rob McEwen has ruined the stereotypes functioning in the mining business, lead the company out of a deep crisis, and is a perfect example of using crowdsourcing, thanks to which sharing an organisation's particular part of intellectual property enables to reveal enormous potential of a group genius [4, pp. 23-27; 18].

Another perfect example of applying the power of virtual societies is the brand called Threadless, which is said to be the symbol of resourcefulness in the creativity sector. Cofounders, Jake Nickell and Jacob DeHart, did not have business intentions at first. In times of starting up Threadless they were both students. From its beginning they treated the project as a way of integrating the design societies from all over the world. Many other events took part along with the project, as Jake's winning in a competition for the best T-shirt organised by New Media Underground Festival. They were starting with only 500 USD in their pockets. The first 2 years of Threadless functioning were connected with investments - in a new series of T-shirts. The founders wanted to create a design virtual society where authors' projects were verified by potential clients, who were given the possibility to evaluate the best T-shirts, up to date. The post popular and the best evaluated (from 1 to 5 points) were then printed by Threadless. At the beginning, Jake and Jacob printed one series per month. After 4 years this number grew to one series per week and the next year six series per week. Each year the company and its societies brought new events. In this case, it took 6 years to find an investor who was interested in the development of Threadless. The undertaking of the two students is not only producing T-shirts, but it is mostly about original projects. Over the time, Threadless' scope of functioning connected with design spread further. They also organised monthly meetings in the Art Institute 'Anonymous Federated' of Chicago with virtual designers, who were telling their stories to the gathered crowd. Threadless are mainly contents, such as: 'Threadless Select' (organised since 2008 with the cooperation with the Rhode Island School of Design), 'Loves Tree', and 'Bestee Award' (which award was higher than 100 thousand USD in 2007). The authors of project come from different continents. Threadless may be described as a Web 2.0. company, where consumers create products which then they buy. Winners receive 2000 USD award, 500 USD to spend in the Threadless shop, and their name is printed on T-shirts with their projects. The undertaking exists thanks to the use of social media. Nowadays, Threadless is a society with over 2.5 million people from all over the world and the number of projects reaches over 500 thousand [14, p. 4; 18].

The iStockphoto, a first Internet portal offering pictures, multimedia and design elements on the principle of royalty-fee (a single payment), founders also based their business on crowdsourcing. Stock photos are ready pictures, which can be legally used in commercial and promotion materials. The company was set up by Bruce Livingstone in May, 2000. Originally, iStockphoto was a free website; however, over the time, it was changed into a model of micropayments and from 2001 it has been a profitable business. Clients searching for pictures to use in the Internet sites, booklets or business presentations, pay 1 USD for, so-called, credit and they can start buying pictures. The costs depend on the resolution; the best quality files may be priced up to 50 points. Artists, designers, photographers from all over the world register in the portal in order to create, work and learn. IStockphoto portal started its functioning in 2000 with a collection of only few photos. Today, it offers vector graphics, video files, music compositions and sound effects. Millions of users enjoy inexpensive and high quality files from the iStockphoto collection. Photographers receive $20 \%$ of the cost price when their picture is being downloaded. Some of the most committed participants of online society may earn through signing an agreement with iStockphoto company and receive $40 \%$ of the cost price of their projects. The founders of iStockphoto involved, hereby, in their entrepreneurship the artistic industry, sharing with millions of users millions of files from a large number of the registered authors. A basic idea is still the same: everyone can freely join the portal; these are not only designers - professionals, but also amateurs, who want to sell their original works, and clients buying necessary digital media [7, pp. 79-80; 19]. 
The development of crowdsourcing has its beginnings abroad, where a very fast progress of it is observed. However, there are also examples of its usage on the Polish market. One of them is bank BZ WBK and its 'Bank of Ideas' platform. The Bank of Ideas is a place where the Internet users, being clients or only sympathisers, can upload their opinions and ideas about the functioning of the bank. A virtual crowd suggests what shall be improved in the bank. The freedom of expression and uploading ideas was also extended to the possibility to vote for the best solutions. Finally, bank BZ WBK implements in practice those ideas which are the most beneficial for their clients, improving, in the same way, their level of service. The Bank of Ideas is, therefore, a perfect form of introducing the dialog with clients, as well as, a valuable source of information. It was created in 2009 and, as for this moment, it implemented 546 ideas, whereas, 41 ideas are partially implemented, 8 are in the process of implementation and 7 are being consulted in the bank. They are concerned with almost every category of bank services - starting from individual accounts to a company's services. Currently, 7515 users, who have altogether uploaded 4389 ideas, are logged in. They have generated over 9816 comments. In 2010, the BZ WBK platform was awarded in the content 'A good design 2010' organised by the Institute of Industrial Design. The Bank of Ideas is a pioneer of the crowdsourcing's tools in Poland. This year, the Western Bank WBK awarded by a prestigious honour - the title of the Company of a Year 2012 [20].

Not only large companies, but also small enterprises or organisations may benefit from implementing crowdsourcing. An example is a regional Touristic Organization. It announced a contest which aim was to acquire new, unconventional souvenirs' projects promoting the Lower Carpathians voivodeship. They shall be connected with cultural traditions of the region, as well as, those modern inspirations [21].

Aretech is a Polish enterprise from MSP sector, which based its model on crowdsourcing. They test software through organisation and management of the tests' processes carried out by real users in their own environments. The project is run with the use of the Internet portal named Testuj.pl. It is the first crowdsourcing testing website, creating testers' society ready to verify every application for desktop and mobile platforms. In this way, with the cooperation of virtual society, the company offers services which control the functionality, usability and safety of applications [22, 23].
Under the motto 'Only Good Ideas' crowdsourcing platform Sprinet.pl works. It is the first marketing platform in Poland, which aim is to link brands with a creative Internet society. As a result, innovative solutions are created mainly in the field of marketing. Sprinet.pl is a site of social character, which was created in 2012 thanks to the financial support from the Operational Program of Innovative Economy. The main aim is to focus the society involved in the process of crowdsourcing, thus, the activity of enterprises, institutions or organisations, willing to improve their products, will be supported. This platform enables to share ideas which are to influence on an organisation's development, as well as, help to solve its problems. Personalised profiles and set of research tools, such as surveys, questionnaires or open questions, involve, additionally, the Internet users in a number of categories from widely understood social life (e.g. media, governmental institutions, health care, computer and electronic industry, investing in cities, education, etc.) in part of which different innovative solutions may be realised. Sprinet is still a young undertaking, however, accomplishing its first projects, such as the contest 'The taste of the region - like at home'. A three-stage competition organised by the Restaurant under the Town Hall in Rzeszów, in part of which one might submit his/her proposition of a regional dish. The winners of four dishes with the highest scores received in-kind prizes. There are 209 users currently registered in the portal, 154 ideas have been submitted as part of 19 projects, from which 7 were accepted. In time, there will be more of such projects. Participating in crowdsourcing undertakings combines pleasure with business, in the same time, offering the possibility to create the reality. The founders of the platform use their activity other than Web 2.0. services, where the newest information about contents, events or ideas are uploaded [24].

The application of crowdsourcing is still developing. More and more complex problems can be solved. A key concept in the process of crowdsourcing is the fact that a well-organised action promotes itself and the Internet users take over some of the ambassadorial responsibility. As a result, message reaches the receivers in very differentiated manners - through channels, which are not used in traditional campaigns. Another important factor is a fresh look, which the receivers often possess. In Poland, crowdsourcing constitutes still a novelty, a new Internet mode; therefore, because of the adopted technique, with a proper use of PR tools, a campaign becomes interesting for media and bloggers. From the conducted observation of the adopted actions, at least two areas may be classi- 
fied as problematic. Cooperating with a company offering outsourcing services for entrepreneurships, one may significantly control the transfer of confidential information through signing additional confidential information agreements or entrusting them only to reliable clients. Using crowdsourcing it is more difficult to preserve the confidentiality of information. If these are tasks with a high confidentiality level, which were previously protected from competition, then crowdsourcing is not the best solution (especially its basic form published to everyone). An option may be extra protection, which is given by some particular platforms, such as hidden content or private one.

From the perspective of a company using crowdsourcing solutions, one has to be aware of the fact that the solution which gains the highest number of users may not be proper for an organisation. An example of an action, which turned out to be a failure, is the project of Henkel company - a contest for the best package of a dishwashing liquid Pril. Users sent projects of packages and then they could evaluate particular solutions, creating, in the same way, the projects' ranking. Henkel company announced that 2 out of 10 best projects will be chosen. In weeks' time the Internet users submitted over 50000 projects. Henkel company, realised that many of the projects having the highest scores, are not the ones that they were expecting. They intervened and, at their own discretion, changed the results. They informed the users about the manipulation of results in an official statement. As a result, the virtual crowd rebelled against the behaviour of the company and extensive discussions on the situation took place in the Internet. All the events caused more damage than benefit. Participants of crowdsourcing are particularly sensitive about injustice, lack of transparency, and clear rules. An example of a company having problems with image is Moleskin - an Italian notebooks' brand, which decided to give an offer to design a logo for Moleskin's blog through an open contest. Regulations of the action turned out to be very unfair for the participants of the contest. The main organiser reserved the copyrights of all the projects submitted in the content. In Poland, such contest would be illegal, as all copyrights may be subscribed only to the winning project. Undertaking crowdsourcing research and realizing them through a content needs to clarify the rules: how the winner will be chosen? who is the owner of copyrights of the winning project? and what is going to happen with remaining projects? Conditions and rules of the contest, as well as, the overall process from its beginning to the end, must be clearly formulated. It is enormously important to think the undertaken actions over when using crowdsourcing in marketing. However, it is worth to remember that crowdsourcing brings number of advantages but, as an effect of inappropriate decisions or communication, it may harmfully influence on the image of the company. Nowadays, companies dealing with crowdsourcing services are developing and they will probably become more specialised.

The quoted examples allow to formulate few conclusions on crowdsourcing. They confirm the fact that it provides a new way of solving problems with the emphasis on model which may be over generalised in different branches of industry for solving a variety of tasks. Crowdsourcing is the Internet model, which may be a strategic way to conduct an enterprise, effectively attracting interested people, who, appropriately motivated, are able to provide the solutions of the highest quality and in a large number. A committed crowd creates solutions and products, working faster and using less workforce than even the greatest minds in their area. Trends observed on worldwide markets enable to state that this strategy will still develop.

\section{Summary}

This article constitutes an introduction to an extensive subject, which is crowdsourcing, through illustrating pioneers and creating an outline of its factors. Crowdsourcing may be defined as a wisdom of the virtual crowd; however, it is not only another mode of the Internet, but an effective tool to gather talents, using cleverness with a simultaneous limitation of costs and time, which were previously necessary to solve a problem. Crowdsourcing is possible only with the application of modern technologies and, for this reason, it is an extremely up-to-date challenge, which develops dynamically and is attractive from the point of view of researchers and entrepreneurs.

\section{$5 \quad$ References}

[1] Tidd J., Bessant J. - Zarzqdzanie innowacjami. Integracja zmian technologicznych, rynkowych i organizacyjnych. Oficyna, Warszawa 2011.

[2] Biniasz D. - Wirtualizacja działalności przedsiębiorstw z wykorzystaniem technologii multimedialnych na przyktadzie przemystu meblarskiego, Zarządzanie Przedsiębiorstwem, Nr 2, 2005.

[3] Abou-Zeid E., Cheng Q. - The effectiveness of innovation: a knowledge management approach. International Journal of Innovation Management, Vol. 8, No. 3, 2004. 
[4] Tapscott D., Williams A.D. Wikinomia. - O wspótpracy, która zmienia wszystko. Wydawnictwa Akademickiei Profesjonalne, Warszawa 2008.

[5] Vescovo F. - Prosumers \& Internet: an empirical study on the use of How to contents. Universita' deglistudi di pavia, 2013.

[6] Zwick D., Bonsu S.K., Darmody A. - Putting Consumers to Work: 'Co-creation 'and new marketing governmentality. Journal of Consumer Culture, Nr 82008.

[7] Brabham Daren C. - Crowdsourcing as a Model for Problem Solving. An Introduction and Cases. "Convergence: The International Journal of Research into New Media Technologies", London, Los Angeles, New Delhi and Singapore Vol. 14(1): 75-90, 2008.

[8] Saxton G.D., Onooh Oh, Rajiv Kishore - Rules of Crowdsourcing: Models, Issues, and Systems of Control. Information Systems Management, Volume 30, Issue 1, 2013.

[9] Bhagwati J., Panagariyai A., Srinivsan T.N. - The Muddles over Outsourcing, Journal of Economic Perspectives, 18 (4).

[10] Howe J. - The Rise of Crowdsourcing, Wired, 14(6),(23.08.13):http://www.wired.com/wired/archive/14.06/crowds.html

[11] O'Reilly T. - What is Web 2.0, (23.08.13): http://oreilly. com/web2/archive/what-is-web-20.html.

[12] Łobejko S., Sosnowska A. - Firma innowacyjna w sieci [w:] Wyzwania rozwojowe matych i średnich przedsiębiorstw. Innowacje, technologie, kryzys.
Zakrzewska-Bielawska A. (red.), Difin, Warszawa 2011.

[13] Hammel, G., Prahalad, C.K. - Przewaga konkurencyjna jutra: Strategie przejmowania kontroli nad branża i tworzenia rynków przyszłości. Business Press, Warszawa 1999.

[14] Zhang Li, Zhang Hongjuan. - Research of Crowdsourcing Model Based on Case Study, (24.08.13), http:// mpss.csce.uark.edu/smsdb/IPSN/Research\%20of\%20 Crowdsourcing\%20Model\%20Based\%20on.pdf.

[15] Massolution. The Crowd in the Cloud: Exploring the Future of Outsourcing, (24.08.13), http://www.lionbridge.com/files/2012/11/Lionbridge-White-Paper_ The-Crowd-in-the-Cloud-final.pdf.

[16] Massolution. Crowdsourcing Industry Report, (23.08.13), http://www.crowdsourcing.org/editorial/ enterprise-crowdsourcing-research-report-by-massolution/11736.

[17] Innocentive, URL (24.08.13), http://www.innocentive.com.

[18] http://www.threadless.com.

[19] http://www.istockphoto.com.

[20] https://bankpomyslow.bzwbk.pl

[21] http://www.crowdsourcing.org.pl/pamiatka-z-podkarpackiego-2013.html

[22] http://testuj.pl/

[23] http://aretech.pl/

[24] https://sprinet.pl/ 